\title{
ASSOCIATION OF SINGLE-NUCLEOTIDE POLYMORHISM C3435T IN THE ABCB1 GENE WITH OPIOID SENSITIVITY IN TREATMENT OF POSTOPERATIVE PAIN
}

\author{
Vanja Dzambazovska-Trajkovska ${ }^{1}$, Jordan Nojkov ${ }^{1}$, Andrijan Kartalov ${ }^{1}$, \\ Biljana Kuzmanovska ${ }^{1}$, Tatjana Spiroska ${ }^{1}$, Redzep Seljmani ${ }^{2}$, Gjorgji Trajkovski ${ }^{2}$, \\ Nadica Matevska-Geshkovska ${ }^{3}$, Aleksandar Dimovski ${ }^{3}$
}

\author{
${ }^{1}$ University Clinic for Anesthesiology, Reanimation and Intensive care, Faculty of Medicine, University \\ "Ss Cyril and Methodius", Skopje, R. Macedonia \\ ${ }^{2}$ University Clinic for Digestive Surgery, Faculty of Medicine, University "Ss Cyril and Methodius", \\ Skopje, R. Macedonia \\ ${ }^{3}$ Faculty of Pharmacy, University “Ss Cyril and Methodius", Skopje, R. Macedonia
}

Corresponding Author: Vanja Dzambazovska Trajkovska, MD MSc, Anesthesiology/ Intensive care specialist University Clinic for Anesthesiology, Reanimation and Intensive care, Faculty of Medicine, University "Ss Cyril and Methodius" Skopje; tel: 00 +389(0)2 0702665 36; e-mail: vanjadztrajkovska@gmail.com

\begin{abstract}
Background: The minimal effective analgesic concentration of opioids required for satisfactory analgesia may differ significantly among the patients. Genetic factors may contribute to the variable response to opioids by affecting their pharmacokinetics or pharmacodynamics.

Methods: Ninety nine patients undergoing abdominal surgery with colorectal anastomosis because of colorectal carcinoma were enrolled in the present study. C34535T was genotyped in all subjects and the patients were divided into three groups according to their genotype: $\mathrm{CC}$-wild type homozygous, CT-mutant heterozygous and TT-mutant homozygous. Intravenous fentanyl, patient controlled analgesia was provided postoperatively for pain control in the first 24 hour after surgery. Opioid consumption, pain scores and the adverse side effects were evaluated.

Results: Our main result is that the patients in the CC genotype group consumed significantly more fentanyl $(375.0 \mu \mathrm{g} \pm 43.1)$ than the patients in the TT group $(295.0 \mu \mathrm{g} \pm 49.1)$ and the CT $(356.4 \mu \mathrm{g}$ \pm 41.8 ) group in the treatment of postoperative pain. The patients in the TT group had lower VAS scores at $6 \mathrm{~h}, 12 \mathrm{~h}, 18 \mathrm{~h}$ and $24 \mathrm{~h}$ postoperatively. There were no significant differences in the side effects among the three groups regarding the vomiting and the sedation score. The patients in the TT group had more frequently nausea score 1 , than the patients in the other two groups.

Conclusion: Our study indicates that the C3435T SNPs of the ABCB1 gene is associated with differences in the opioid sensitivity. The ABCB1 polymorphism may serve as an important genetic predictor to guide the acute pain therapy in postoperative patients.
\end{abstract}

Keywords: Fentanyl, ABCB1, Postoperative analgesia

\section{Introduction}

Opioids are generally considered as the first line therapy for patients with moderate to severe postoperative pain. The dose of opioids required to achieve sufficient postoperative pain relief is highly variable among patients. The inter-individual variations in response to opioids can partly be attributed to age, gender, weight
(BMI), renal or liver functions. However, as each patient often responds differently to specific opioids, providing adequate analgesia for individual patients without concomitant development of adverse effects is still a major challenge.

Each patient may respond differently to specific different opioids. There still exists a need to sort out the multiple explanations for 
some variability encountered with the human responses to opioids. The minimal effective analgesic concentration of opioids required for satisfactory analgesia may considerably vary among the patients [1]. Genetic factors may contribute to the variable response to opioids by affecting their pharmacokinetics (drug metabolizing enzymes and transporters) or pharmacodynamics (receptor and signal transduction).

Drug transporters are important structural proteins that can influence the absorption, distribution and elimination of opioids [2]. In the gastrointestinal tract and hepatocytes they have the ability to influence the bioavailability of the orally administrated opioids by restricting or facilitating the intestinal absorption and facilitating presystemic biliary elimination [3, 4]. In particular, the transporter expression at the blood-brain barrier has the potential to significantly influence the clinical efficacy and safety of opioids, whose major site of action lies within the central nervous system [2]. Both efflux and uptake carrier systems have been implicated in the transport of opioids (drugs and peptides), with multiple transporters often functionning in concert to facilitate the efficient transfer of substrates across biological membranes. The 2 major families of drug transporters of relevance to opioid pharmacokinetics are the ATP binding cassette (ABC) superfamily of efflux transporters, and the solute carrier (SLC) superfamily of influx transporters. The ABC superfamily of efflux transporter consist of nearly 50 known human members divided in 7 sub-families. The most characteristic of the ABC transporters is the ABCB1 MDR1, P - glycolprotein (P-gp) efflux transporter which functions at the capillary endothelial cells of the blood brain barrier (with the ABCC family being less well studied). Opioid induced analgesia is increased and prolonged in mice lacking P g-p. Morphine, methadone, loperamide, and fentanyl have all been confirmed as P-gp substrates [1].

The most investigated of the common $\mathrm{ABCB} 1$ genetic polymorphisms is the non-synonymous exon $26 \mathrm{SNP}, \mathrm{C} 3434 \mathrm{~T}$, which is observed with a frequency of $50-60 \%$ in Caucasians, $40-50 \%$ in Asians, and $10-30 \%$ in Africans. [5-8]. There was a significant relationship between 3435 genotype and the extent of loperamide miotic effects following $\mathrm{p}$-gp inhibition by quinidine [1].

The ABCB1 gene is composed of 28 exons ranging in size from 49 to 299 base pairs, enco- ding an mRNA of $4.5 \mathrm{~kb}$. The most common polymorphisms found in $\mathrm{ABCB} 1$ are $1236 \mathrm{C}>\mathrm{T}$, $2677 \mathrm{G}>\mathrm{T} / \mathrm{A} / \mathrm{C}$, and $3435 \mathrm{C}>\mathrm{T}$. It has been suggested that the genetic variations in $\mathrm{ABCB} 1$ could be a cause of inter-individual differences in drug response [9]. In this study we investigated the C3435T Single Nucleotide Polymorphisms - SNPs of ABCB1 where $\mathrm{C}>\mathrm{T}$. Thus, the major allele is $\mathrm{CC}$, the heterozygous minor allele is $\mathrm{CT}$ and homozygous minor allele is TT.

The aim of the study is to evaluate the association between C3435T and the opioid consumption in the acute postoperative period in patients who have undergone abdominal surgery with colorectal anastomosis. Additionally, we explored the association between C3435T and the opioid side effects in the acute postoperative period in the same population.

\section{Methods}

\section{Study subjects and analgesia}

This was a prospective study approved by the institutional Ethics Committee (No 03$6608 / 2$ ). A signed informed consent was obtained from all patients. Between July 2013 and February 2016, 100 patients with the American Society of Anesthesiologist physical status of IIII aged 35-75 years, and undergoing abdominal surgery with colorectal anastomosis because of colorectal carcinoma, were enrolled in the present study. The main exclusion criteria included liver and renal disease, history of chronic pain, severe cardiovascular disease, diabetes mellitus, psychiatric disorders, pregnancy, lactation, allergy to opioids, unwillingness to cooperate in the pain assessment, and administration of non-steroidal anti-inflammatory analgetics and/or opioids one week before surgery. All patients underwent surgery under combined general/epidural anesthesia.

After recovering from anesthesia, all patients received fentanyl by intravenous patientcontrolled analgesia (PCA) using a PCA pump containing $100 \mathrm{ml}$ saline $0.9 \%, 1 \mathrm{mg}$ fentanyl. The PCA pump was programmed to give a 20 $\mu \mathrm{g}$ bolus $(2 \mathrm{ml})$ of solution with 5-min lockout time, $5 \mu \mathrm{g} \cdot \mathrm{h}^{-1}$ fentanyl background infusion and maximum $145 \mu \mathrm{g} \cdot \mathrm{h}^{-1}[10]$. The delivered fentanyl dose was automatically recorded by the pump. Nausea and vomiting following abdominal surgery are common, therefore all patients were intravenously administered $30 \mathrm{mg}$ metoclopramide divided into three doses. The pati- 
ents were monitored closely to prevent fentanyl overdose (pulse oxygen saturation, heart rate and noninvasive blood pressure).

Pain at rest was assessed using $10 \mathrm{~cm}$ VAS with a range $0-10$, with no pain as zero and the worst possible pain as ten. Successful analgesia was defined as a postoperative VAS pain score $\leq 3$. The side effects were recorded every $6 \mathrm{~h}$ after completion of the operation, i.e. at $6,12,18$ and $24 \mathrm{~h}$. Patients rated their nausea on a four-point scale (0-no nausea; 1 -mild nausea, 2-moderate nausea; 3-severe nausea). Vomiting was assessed as events occurring in the first $24 \mathrm{~h}$. Sedation was assessed using Ramsay sedation score ( 0 awake, 6 unresponsive to a strong, painful stimuli). [11-13].

\section{Statistical analysis}

The statistical data processing was done in the statistical program SPSS 17 for Windows. The testing of normality in the distribution of the data was used Kolmogorov-Smirnov and Shapiro-Wilk's W test. Categorical traits displayed by absolute and relative representation with quantitative traits mean, SD. For comparison of the three genotypes in relation to the variables analyzed were used the Chi-square test, Fisher exact test, Student's t test, One-way analysis of variance (post hoc Bonferroni test). The correlation between the consumption of fentanyl with age and duration of operative intervention was analyzed with the Pearson's coefficient of linear regression. Concerning the level of significance or importance, the value of $\mathrm{p}<0.05$ was taken, a significant higher value than $\mathrm{p}<0.01$.

\section{Genotyping}

Venous blood samples $(2 \mathrm{ml})$ were collected from all patients in the study. Genomic DNA was extracted from whole blood using SaMag Blood DNA Extraction Kit (Sacace Biotechnologies, Como, Italy) on an automatic DNA extractor (SaMag - 12 System, Sacace Biotechnologies, Como, Italy) according to the manufacturer's provided protocol. The quantity and quality of the extracted genomic DNA was determined using NanoDrop 2000 spectrophotometer (Thermo Scientific, USA) with measurements performed at 260 and $280 \mathrm{~nm}$. The ABCB1 C3435T (rs1045642) polymorphism was genotyped using a TaqMan ${ }^{\circledR}$ Drug metabolism genotyping assay (ID C 7586657 20, Applied biosystems, Life Technologies, USA). Amplification reactions were performed in a total volume of $25 \mu \mathrm{L}$ containing $20 \mathrm{ng}$ genomic DNA, $12.5 \mu \mathrm{L} 2 \times$ Taqman Universal PCR
Master Mix and $1.25 \mu \mathrm{L} 20 \times$ Drug Metabolism Genotyping Assay Mix. Thermal cycling was performed according to the manufacturer's recommended protocols using a Stratagene MX3005P real-time PCR system (Agilent Technologies). Both positive and negative controls were included in every genotyping assay.

\section{Results}

Out of 100 patients, one did not complete the procedure and was excluded due to problems with DNA isolation. Patients were divided into CC, CT and TT groups after genotyping. Among the remaining 99 subjects, there were 28 wild type homozygotes (CC), 45 heterozygotes (CT), and 26 mutant homozygotes (TT). (Table 1). There were no significant differences in the demographic characteristics among the three genotype groups with regard to sex, age, weight, height, duration of surgery and ASA score (Table 2). In the remaining 99 patients, there were no PCA device failures and no intolerable opioid side effects. There was significant differences in VAS scores between $\mathrm{CC}$ and TT groups, and CT and TT. VAS scores $6 \mathrm{~h}$ after surgery were CC $4.39 \pm 13$; CT $3.64 \pm 1.3$ and $2.1 \pm 92.0$ for TT genotype group. VAS scores $12 \mathrm{~h}$ after surgery were $3.18 \pm 0.18$ in group $\mathrm{CC}, 3.0 \pm 0.7 \mathrm{CT}$, and $1.73 \pm 1.2$ for group TT. After $18 \mathrm{~h}$ VAS scores for three groups were $2.61 \pm 0.6 \mathrm{CC} ; 2.2 \pm 0.7$ in group CT and $1.54 \pm 0.9$ in group TT. VAS scores $24 \mathrm{~h}$ postoperatively for three groups were $1.82 \pm 0.9$ for CC group; $1.56 \pm 0.7$ among the patients in CT group, and $1.08 \pm 0.8$ for TT group (Table 3 ). There were no significant differences in side effects among the three groups regarding vomiting and sedation score. The patients in the TT group had more frequently nausea score 1 than the patients in the other two groups (Table 4). The patients in the CC group consumed significantly more fentanyl $(375.0 \mu \mathrm{g} \pm 43.1)$ than the patients in the TT group $(295.0 \mu \mathrm{g} \pm 49.1)$ and CT (356.4 $\mu \mathrm{g} \pm 41.8)$ group (Table 5).

Table 1

Genotype distribution of $A B C B 1$ (C3435) in 99 patients

\begin{tabular}{cc}
\hline ABCB1 & $\mathbf{N}(\%)$ \\
\hline CC & $28(28.28)$ \\
CT & $45(45.45)$ \\
TT & $26(26.26)$ \\
All & $99(100)$ \\
\hline
\end{tabular}

$\mathrm{CC}$, wild type homozygous; CT, mutant heterozygous; TT mutant homozygous 
Table 2

Demographic and clinical characteristics of $A B C B 1$ genotype groups

\begin{tabular}{|c|c|c|c|c|}
\hline Characteristics & $\begin{array}{c}\text { ABCB1 CC } \\
(n=28)\end{array}$ & $\begin{array}{c}\text { ABCB1 CT } \\
(\mathrm{n}=45)\end{array}$ & $\begin{array}{c}\text { ABCB1 TT } \\
(n=26)\end{array}$ & $\mathrm{p}$ value \\
\hline \multicolumn{5}{|l|}{$\operatorname{Sex} n(\%)$} \\
\hline Male $n=59$ & $17(60.71)$ & $26(57.78)$ & $16(61.54)$ & \multirow[t]{2}{*}{${ }^{a} p=09$} \\
\hline Female $\mathrm{n}=40$ & $11(39.29)$ & $19(42.22)$ & $10(38.46)$ & \\
\hline \multicolumn{5}{|l|}{ Age, years } \\
\hline$($ mean $\pm \mathrm{SD})$ & $60.18 \pm 9.9$ & $60.2 \pm 9.7$ & $56.12 \pm 8.7$ & ${ }^{b} \mathrm{p}=018$ \\
\hline \multicolumn{5}{|l|}{ Height $(\mathrm{cm})$} \\
\hline$($ mean $\pm \mathrm{SD})$ & $170.36 \pm 8.4$ & $171.09 \pm 8.6$ & $171.19 \pm 6.0$ & ${ }^{b} \mathrm{p}=091$ \\
\hline \multicolumn{5}{|l|}{ Weight (kg) } \\
\hline$($ mean $\pm \mathrm{SD})$ & $71.36 \pm 12.7$ & $74.84 \pm 12.6$ & $77.58 \pm 10.6$ & ${ }^{b} p=017$ \\
\hline \multicolumn{5}{|l|}{ ASA n $(\%)$} \\
\hline 1 & $6(21.43)$ & $6(13.33)$ & $4(15.38)$ & \multirow{3}{*}{${ }^{\mathrm{c}} 0.14$} \\
\hline 2 & $20(71.43)$ & $39(86.67)$ & $19(73.08)$ & \\
\hline $3 \quad . \quad 5$ & $2(7.14)$ & 0 & $3(11.54)$ & \\
\hline \multicolumn{5}{|c|}{ Duration of surgery (min) } \\
\hline$($ mean $\pm \mathrm{SD})$ & $186.25 \pm 34.2$ & $198.56 \pm 38.6$ & $191.15 \pm 35.5$ & ${ }^{b} p=036$ \\
\hline
\end{tabular}

* Continuous variables expressed as mean + standard deviation.

* ${ }^{\mathrm{a}}$ (Chi-square test) ${ }^{\mathrm{b}}$ (Analysis of Variance) ${ }^{\mathrm{c}}$ (Fisher exact test)

* ASA - American Society of Anesthesiologists

Table 3

ABCB1 C3435T polymorphism and postoperative pain in $6 \mathrm{~h}, 12 \mathrm{~h}, 18 \mathrm{~h}$ and $24 \mathrm{~h}$ postoperatively

\begin{tabular}{lcccc}
\hline Characteristics & $\begin{array}{c}\text { ABCB1 CC } \\
(\mathrm{n}=28)\end{array}$ & $\begin{array}{c}\text { ABCB1 CT } \\
(\mathrm{n}=45)\end{array}$ & $\begin{array}{c}\text { ABCB1 TT } \\
(\mathrm{n}=26)\end{array}$ & $\mathrm{p}$ value \\
\hline $\begin{array}{l}\text { VAS (6h) } \\
(\text { mean } \pm \text { SD) }\end{array}$ & $4.39 \pm 1.3$ & $3.64 \pm 1.3$ & $2.19 \pm 2.0$ & ${ }^{\mathrm{b}} \mathrm{p}=0000003^{* *}$ \\
$\begin{array}{l}\text { VAS }(12 \mathrm{~h}) \\
(\text { mean } \pm \text { SD) }\end{array}$ & $3.18 \pm 0.8$ & $3.0 \pm 0.7$ & $1.73 \pm 1.2$ & ${ }^{\mathrm{b}}<0001$ \\
$\begin{array}{l}\text { VAS }(18 \mathrm{~h}) \\
(\text { mean } \pm \mathrm{SD})\end{array}$ & $2.61 \pm 0.6$ & $2.2 \pm 0.7$ & $1.54 \pm 0.9$ & $\mathrm{~b}_{\mathrm{p}}=0000001^{* *}$ \\
$\begin{array}{l}\text { VAS }(24 \mathrm{~h}) \\
(\text { mean } \pm \mathrm{SD})\end{array}$ & $1.82 \pm 0.9$ & $1.56 \pm 0.7$ & $1.08 \pm 0.8$ & ${ }^{\mathrm{b}} \mathrm{p}=00023^{* *}$ \\
\hline
\end{tabular}

* Post hoc analysis Bonferroni. VAS (6h) $1 \mathrm{scs} 3 \mathrm{p}=0.00011^{*} * 2 \mathrm{vs} 3 \mathrm{p}=0.0006 * *$ VAS (12h) $1 \mathrm{Bc} 3 \mathrm{p}=0.0001 * *$

* 2vs3 p $=0.0001^{* *}$ VAS (18h) 1 вс3 $\mathrm{p}=0.0001^{* *} 2 \mathrm{vs} 3 \mathrm{p}=0.0007 * * \operatorname{VAS}(24 \mathrm{~h}) 1 \mathrm{sc} 3 \mathrm{p}=0.0018^{* *}$

* 2vs3 p $=0.035 * * \mathrm{p}<0.05 * * \mathrm{p}<0.01$

* VAS - visual analogue scale

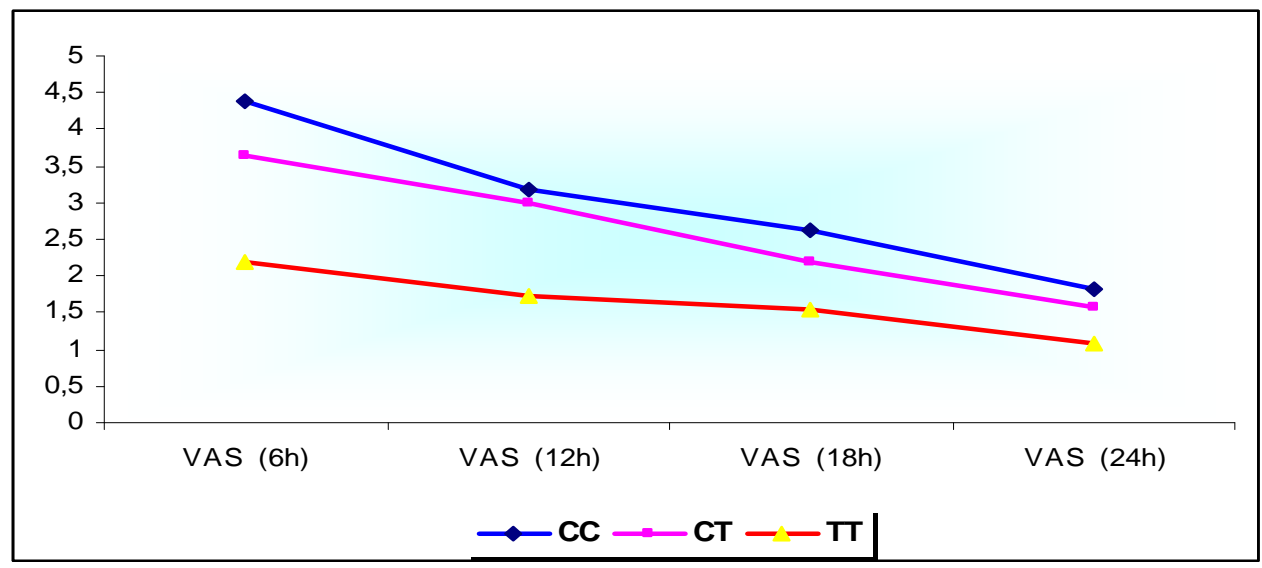

Fig. 1 - Pain assessment by visual analogue scale (VAS). VAS (mean+standard deviation) was recorded at $6 \mathrm{~h}, 12 \mathrm{~h}$, $18 \mathrm{~h}$ and $24 \mathrm{~h}$ after the completion of the operation in three genotype groups CC, CT and TT. CC, wild type homozygous; CT, mutant heterozygous; TT mutant homozygous 
Table 4

Side-effects of fentanyl delivered via patient-controlled analgesia (PCA) for patients receiving PCA, in three genotype groups

\begin{tabular}{lcccc}
\hline Characteristics & $\begin{array}{c}\text { ABCB1 CC } \\
(\mathrm{n}=28)\end{array}$ & $\begin{array}{c}\text { ABCB1 CT } \\
(\mathrm{n}=45)\end{array}$ & $\begin{array}{c}\text { ABCB1 TT } \\
(\mathrm{n}=26)\end{array}$ & p value \\
\hline Nausea $-\mathrm{n}(\%)$ & $24(85.71)$ & $43(95.56)$ & $18(69.23)$ & \\
0 & $3(10.71)$ & $2(4.44)$ & $4(15.38)$ & ${ }^{\mathrm{c}} 0.014$ \\
1 & $1(3.57)$ & 0 & $4(15.38)$ & \\
2 & & & & \\
Vomiting-n (\%) & $27(96.43)$ & $44(97.78)$ & $25(96.15)$ & 10 \\
0 & $1(3.57)$ & $1(2.22)$ & $1(3.85)$ & \\
1 & & & & \\
Sedation-n $(\%)$ & $28(100)$ & $43(95.56)$ & $23(88.46)$ & ${ }^{\mathrm{c}} 0.12$ \\
0 & 0 & $2(4.44)$ & $3(11.54)$ & \\
\hline
\end{tabular}

${ }^{c}$ (Fisher exact test)

CC, wild type homozygous; CT, mutant heterozygous; TT mutant homozygous.

Patients rated their nausea using a four -point scale ( 0 , no nausea; 1 , mild nausea; 2, moderate nausea; 3 severe nausea). Vomiting was assessed as events occurring in $24 \mathrm{~h}$. Sedation was assessed using the Ramsey sedation score (0, awake; 6 unresponsive to strong painful stimuli).

Table 5

Postoperative consumption of fentanyl $(\mu \mathrm{g})$ in three genotype groups

\begin{tabular}{lcccc}
\hline ABCB1 CC & ABCB1 CT & ABCB1 TT & \\
& $(\mathrm{n}=28)$ & $(\mathrm{n}=45)$ & $(\mathrm{n}=26)$ & $\mathrm{p}$ value \\
\hline Postoperative consumption of fentanyl $(\mu \mathrm{g})$ & & & \\
$($ mean \pm SD $)$ & $375,0 \pm 43.1$ & $356,4 \pm 41.8$ & $295,0 \pm 49.1$ & $\mathrm{~b}<0.0001$ \\
\hline
\end{tabular}

Post hoc analysis Bonferroni $* * \mathrm{p}<0.01$

\section{Discussion}

Our main result is that, in Macedonian patients who underwent abdominal surgery with colorectal anastomosis due to colorectal carcinoma, subjects with ABCB1 3435T allele (TT mutant type homozygous) received less fentanyl in the early postoperative period and had lower VAS scores. According to our results subjects in this group are "good respondent" to fentanyl, while patients in the CC group (wild type homozygous) are "bad respondent". The subjects in the CT group (mutant heterozygous) are "moderate respondents". This provides support for potential use of genetic data in predicting the fentanyl doses for adequate postoperative pain control. Some evidence suggests that other variables (e.g., age, sex and type of surgery) may also influence the postoperative pain [14-15]. There are conflicting results in literature regarding the influence of SNPs in ABCB1 gene on both, effects and side effects of opioids. It has been suggested that the TT carriers of
C3435T were good respondents to morphine while those with $\mathrm{CC}$ or $\mathrm{CT}$ were moderate respondents. It has been speculated that the absorption of morphine is reduced in the $\mathrm{CC}$ carriers due to the effective efflux by P-gp in gut and/or through the blood brain barrier and consequently reducing the bioavailability of morphine for the receptors in brain. Conversely the TT carriers with abnormal function of P-gp should have a higher concentration of morphine [16]. The C3435T ABCB1 SNP has recently been associated with a different need for morphine in humans. Meineke et al. showed that patients carrying the TT genotype of the C3435T ABCB1 SNP, associated in other tissues with lower P-gp expression, had higher morphine cerebrospinal fluid concentrations than patients carrying the wild type $\mathrm{C}$ allele, associated with higher P-gp expression. These pharmacogenetics data obtained in humans are consistent with the involvement of P-gp in morphine brain disposition [17]. Age and prior use of psychotro- 
pic agents are associated with postoperative morphine dose requirements. Whether ABCB1 polymorphisms might predict morphine side effects remains to be determined [18]. Previous investigations have observed that opioids are the substrates for P-gp involved in drugs cellular membrane permeability, disposition, and therefore analgesia effect in CNS [19]. In the study of Gong et al., they failed to reveal any significant difference in $24 \mathrm{~h}$ opioids doses among the subjects carrying various ABCB1 C3435T phenotypes in patients with cancer pain. However, when they measured using weight-surface area-adjusted-24h-opioids doses instead, TT homozygotes tended to require significantly lower opioids intake dosage than CC/CT carriers. [20]. In the study of Candiotti et al. where C3435T was genotyped in 152 patients undergoing a nephrectomy, authors found an association between the ABCB1 polymorphism (C3435T) and inter individual variations in opioid consumption in the acute postoperative period after nephrectomy. Analyzing the pain scores from 24-hour postoperative period, they observed that the $\mathrm{CC}$ genotype demonstrated the highest numerical pain score, the CT group an intermediate score, and the TT genotype the lowest. The same trend was observed in the 6 and 12 hour postoperative pain scores [21]. It has been reported that variants in $\mathrm{ABCB} 1$ are associated with the central side effects of opioids such as sedation, confusion, and hallucination in chronic cancer patients [2]. In our study we didn't find association between genetic polymorphisms of ABCB1 C3435T SNP and opioids side effects: vomiting and sedation. Patients in the TT genotype group had more frequently nausea score 2 than $\mathrm{CC}$ and CT group. Coulbault et al. suggested that $\mathrm{ABCB} 1$ polymorphisms could predict the side effects of morphine remains to be determined [18]. In the study of Candiotti et al. the authors also investigated a possible correlation between morphine related side effects (symptomatic nausea/vomiting) and the ABCB1 gene SNP. Their data showed that the CC genotype demonstrated the numerically lowest usage of emesis medication, the CT genotype demonstrated intermediate usage levels, and the TT genotypes showed the highest usage, but there were no statistically significant differences among the three genotype groups for emesis medications usage at 24 hours after surgery [21]. Wallden et al. also considered that the genetic polymerphism does not explain the nausea and vomi- ting caused by fentanyl. However, they found that the incidence of nausea and vomiting was higher in patients with inhibit gastric motility. This finding provides another explanation for postoperative nausea and vomiting, namely this may be associated with the opioid-induced changes in gastric motility [22].

Our study has some limitations. This was strictly a gene association study trial and as such opioid levels were not measured in the CNS or blood. Additionally, the study only enrolled patients undergoing abdominal surgery which is very painful. Secondly, the mixed gender study population may have increased variability in postoperative fentanyl requirements, although no statistically significant differences in gender were found between the different genotypes. In addition, only one gene polymorphism was analyzed, leaving a number of gens with functional significance to be assessed in future studies.

\section{Conclusion}

Our study indicates that the C3435T single nucleotide polymorphism of the ABCB1 gene is associated with differences in postoperative opioid consumption in patients who underwent abdominal surgery with colorectal anastomosis. The ABCB1 polymorphism may serve as a genetic predictor to guide acute pain therapy in postoperative patients.

\section{REFERENCES}

1. Smith HS. Variations in opioid responsiveness. Pain Physician. 2008 Mar-Apr; 11(2): 237-48.

2. Somogyi AA, Barratt DT, Coller JK. Pharmacogenetics of opioids. Clin Pharmacol Ther. 2007 Mar; 81(3): 429-44.

3. Jones AK, Watabe H, Cunningham VJ, Jones T. Cerebral decreases in opioid receptor binding in patients with central neuropathic pain measured by [11C] diprenorphine binding and PET. Eur J Pain. 2004 Oct; 8(5): 479-85.

4. Maarrawi J, Peyron R, Mertens P, Costes N, Magnin M, Sindou M, Laurent B, Garcia-Larrea L Differential brain opioid receptor availability in central and peripheral neuropathic pain. Pain. 2007 Jan; 127(1-2): 183-94.

5. Kerb R. Implications of genetic polymorphisms in drug transporters for pharmacotherapy. Cancer Lett 2006; 234: 4-33. 51.

6. Cascorbi I. Role of pharmacogenetics of ATP-binding cassette transporters in the pharmacokinetics of drugs. Pharmacol Ther 2006; 112: 457-473. 52.

7. Ameyaw MM, Regateiro F, Li T, Liu X, Tariq M, Mobarek A, Thornton N, Folayan GO, Githang's J, Indalo A, Ofori-Adjei D, Price-Evans DA, McLeod HL. MDR1 pharmacogenetics: Frequency of the C3435T 
mutation in exon 26 is significantly influenced by ethnicity. Pharmacogenetics 2001; 11: 217-221. 53.

8. Skarke C, Jarrar M, Schmidt H, Kauert G, Langer M, Geisslinger G, Lötsch J. Effects of ABCB1 (multidrug resistance transporter) gene mutations on disposition and central nervous effects of loperamide in healthy volunteers. Pharmacogenetics 2003; 13: 651-66.

9. Rhodin A, Grönbladh A, Ginya H, Nilsson KW, Rosenblad A, Zhou Q, et al. Combined analysis of circulating $\beta$-endorphin with gene polymorphisms in OPRM1, CACNAD2 and ABCB1 reveals correlation with pain, opioid sensitivity and opioid-related side effects. Mol Brain. 2013 Feb 12;6:8. doi: 10.1186/1756-6606-6-8.

10. Zhang W, Yuan JJ, Kan QC, Zhang LR, Chang YZ, Wang ZY. Study of the OPRM1 A118G genetic polymorphism associated with postoperative nausea and vomiting inducedby fentanyl intravenous analgesia. Minerva Anestesiol. 2011 Jan; 77(1): 33-9.

11. Zhang W, Chang YZ, Kan QC, Zhang LR, Lu H, Chu QJ, et al. Association of human micro-opioid receptor gene polymorphism A118G with fentanyl analgesia consumption in Chinese gynaecological patients. Anaesthesia. $2010 \mathrm{Feb}$; 65(2): 130-5.

12. Sia AT, Lim Y, Lim EC, Goh RW, Law HY, Landau R, et al. A118G Single Nucleotide Polymorphism of Human-Opioid Receptor Gene Influences Pain Perceptionand Patient-controlled Intravenous Morphine Consumptionafter Intrathecal Morphine for Postcesarean Analgesia. Anesthesiology 2008; 109: 520-6.

13. Chou WY, Yang LC, Lu HF, Ko JY, Wang CH, Lin $\mathrm{SH}$, et al. Association of mu-opioid receptor gene polymorphism (A118G) with variations in morphine consumption for analgesia after total knee arthroplasty. Acta Anaesthesiol Scand 2006; 50: 787-792.

14. Bisgaard T, Klarskov B, Rosenberg J, Kehlet H. Characteristics and prediction of early pain after laparoscopic cholecystectomy. Pain 2001; 90: 261-9.

15. Cepeda MS, Carr DB. Women experience more pain and require more morphine than men to achieve a similar degree of analgesia. Anesthesia and Analgesia 2003; 97: 1464-8.

16. Bastami S, Gupta A, Zackrisson AL, Ahlner J, Osman A, Uppugunduri S. Influence of UGT2B7, OPRM1 and $\mathrm{ABCB} 1$ gene polymorphisms on postoperative morphine consumption. Basic Clin Pharmacol Toxicol. 2014 Nov; 115(5): 423-31.

17. Meineke I, Freudenthaler S, Hofmann U, Schaeffeler E, Mikus G, Schwab M, et al. Pharmacokinetic modelling of morphine, morphine-3-glucuronide and morphine-6-glucuronide in plasma and cerebrospinal fluid of neurosurgical patients after short-term infusion of morphine. Br J Clin Pharmacol. 2002 Dec; 54(6): 592-60.

18. Coulbault L, Beaussier M, Verstuyft C, Weickmans H, Dubert L, Trégouet D, et al. Environmental and genetic factors associated with morphine response in the postoperative period. Clin Pharmacol Ther. 2006 Apr; 79(4): 316-24.

19. Ambudkar SV, Kimchi-Sarfaty C, Sauna ZE, Gottesman MM. P-glycoprotein: from genomics to mechanism. Oncogene. 2003 Oct 20; 22(47): 7468-85.

20. Gong XD, Wang JY, Liu F, Yuan HH, Zhang WY, Guo YH, Jiang B. Gene polymorphisms of OPRM1 A118G and $\mathrm{ABCB} 1 \mathrm{C} 3435 \mathrm{~T}$ may influence opioid requirements in Chinesepatients with cancer pain. Asian Pac J Cancer Prev. 2013; 14(5): 2937-43.

21. Candiotti K, Yang Z, Xue L, Zhang Y, Rodriguez Y, Wang L, et al. Single-nucleotide polymerphism $\mathrm{C} 3435 \mathrm{~T}$ in the ABCB1 gene is associated with opioid consumption in postoperative pain. Pain Med. 2013 Dec; 14(12): 1977-84.

22. Walldén J, Lindberg G, Sandin M, Thörn SE, Wattwil M. Effects of fentanyl on gastric myoelectrical activity: a possible association with polymorphisms of the mu-opioid receptor gene?Acta Anaesthesiol Scand. 2008 May; 52(5): 708-15.

23. Gong XD, Wang JY, Liu F, Yuan HH, Zhang WY, Guo YH, Jiang B. Gene polymorphisms of OPRM1 A118G and ABCB1 C3435T may influence opioid requirements in Chinesepatients with cancer pain. Asian Pac J Cancer Prev. 2013; 14(5): 2937-43.

Резиме

\section{ПОВРЗАНОСТ НА ЕДИНЕЧНИОТ НУКЛЕОТИДЕН ПОЛИМОРФИЗАМ \\ НА С3435Т ОД АВСВ1 ГЕНОТ СО ОПИОИДНАТА ОСЕТЛИВОСТ ВО ТРЕТМАНОТ НА ПОСТОПЕРАТИВНАТА БОЛКА}

\section{Вања Џамбазовска-Трајковска ${ }^{1}$, Јордан Нојков ${ }^{1}$, Андријан Карталов ${ }^{1}$, Билјана Кузмановска ${ }^{1}$, Татјана Спироска ${ }^{1}$, Реџеп Селмани ${ }^{2}$, Ѓрѓ́ Трајковски ${ }^{2}$, Надица Матевска-Гешковска ${ }^{3}$, Александар Димовски ${ }^{3}$}

${ }^{1}$ Клиника за анестезија, реанимација и интензивно лекување, Медицински факултет, Универзитет „Св. Кирил и Методиј“, Скопје, Р. Македонија

${ }^{2}$ Универзитетска клиника за дигестивна хирургија, Медицински факултет, Универзитет „Св. Кирил и Методиј“, Скопје, Р. Македонија ${ }^{3}$ Фармацевтски факултет, Универзитет „Св. Кирил и Методиј“, Скопје, Р. Македонија

Вовед: Минималната ефективна концентрација на опиоиден аналгетик може значително да се разликува помеѓу пациентите. Генетските фактори кои влијаат врз фармакокинетиката и фармакодинамиката на опиоидните аналгетици може да придонесат за различната осетливост на опиоидните аналгетици.

Пациенити и метиояи: Во студијата беа вклучени 99 пациенти оперирани од колоректален карцином. Кај сите пациенти беше земена 
венска крв за ДНК-изолација и генотипизација на С3435T од АВCВ1 генот. Според генотипот, пациентите беа поделени во три групи: СС-хомозиготи со див тип алели, СТ-хетерозиготи со мутантни алели и ТТ-хомозиготи со мутантни алели. Кај сите пациенти постоперативно беше даден фентанил на PCA-пумпа (patient controlled analgesia). Степенот на болка, потрошувачката на фентанил и несаканите ефекти беа корелирани со резултатите од генетска анализа.

Резулйайи: Пациентите со генотип СС консумирале значително повеќе фентанил $(375,0 \mu \mathrm{g}$ $\pm 43,1)$, од пациентите во ТТ генотипската група $(295,0 \mu \mathrm{g} \pm 49,1)$ и СТ-групата $(356,4 \mu \mathrm{g} \pm 41,8)$ во третманот на постоперативна болка. Пациентите во ТТ-групата имаа понизок степен на болка според VAS-скалата по 6 часа, 12 часа, 18 часа и 24 часа по операција. Нема значајни разлики во несакани ефекти кај трите генотипски групи во однос на инциденца на постоперативно повраќање и седација. Пациентите во групата ТТ имале почесто гадење степен 1, за разлика од пациентите во другите две групи.

Заклучок: Нашата студија покажува дека полиморфизмите на С3435T од генот АВCB1 се поврзани со разликите во степенот на болка и потрошувачката на фентанил кај пациенти кои биле оперирани од колоректален карцином. Генетскиот полиморфизам на С 3435 Т може да послужи како важен генетски предиктор при третман на постоперативна болка.

Клучни зборови: фентанил, АВСВ1, постоперативна аналгезија 